\title{
Phylogenetic relationships of Erysimum (Brassicaceae) from the Baetic Mountains (SE Iberian Peninsula)
}

\author{
Mohamed Abdelaziz ${ }^{1,2, *}$, A. Jesús Muñoz-Pajares ${ }^{2,3}$, Juan Lorite ${ }^{4}$, M. Belén Herrador ${ }^{5}$, Francisco Perfectti \& José M. Gómez ${ }^{5,6}$ \\ ${ }^{1}$ Biological and Environmental Sciences, School of Natural Sciences, University of Stirling, Stirling FK9 4LA, United Kingdom \\ ${ }^{2}$ Department of Genetics, University of Granada, 18071 Granada, Spain \\ ${ }^{3}$ Centro de Investigação em Biodiversidade e Recursos Genéticos, CIBIO, Campus \\ Agrário de Vairão, Rua Padre Armando Quintas, 4485-661 Vairão, Portugal \\ ${ }^{4}$ Department of Botany, University of Granada, 18071 Granada, Spain \\ ${ }^{5}$ Department of Ecology, University of Granada, Granada, Spain \\ ${ }^{6}$ Departament of Functional and Evolutionary Ecology, Estación Experimental de Zonas Aridas (EEZA-CSIC), Almería, Spain \\ mohamed.abdelazizmohamed@stir.ac.uk; ajesusmp@cibio.up.pt; jlorite@ugr.es; belenhe@ugr.es; fperfect@ugr.es; jmgreyes@eeza.csic.es
}

\begin{abstract}
Abdelaziz, M., Muñoz-Pajares, A.J., Lorite J., Herrador, M.B., Perfectti, F. \& Gómez, J.M. 2014. Phylogenetic relationships of Erysimum (Brassicaceae) from the Baetic Mountains (SE Iberian Peninsula). Anales Jard. Bot. Madrid 71(1): e005.

The Baetic mountains, located in the southern Iberian Peninsula, is a major hotspot of biodiversity in the Mediterranean Basin, constituting one of the most important glacial refugia for vascular plants in Europe. Despite their relatively limited extension, the Baetic Mountains contain almost $50 \%$ of the total endemic Erysimum species in the Iberian Peninsula. The broadly distributed Erysimum genus has diversified profusely in the Mediterranean region, with more than a hundred species described in the area, out of a total of c. 200 species included in the genus. We used two plastid DNA regions ( $n d h F$ and $t r n T-L$ ) and one nuclear DNA region (ITS1-5.8S rDNA-ITS2), with 3,556 bp total length, to carry out phylogenetic analysis by Bayesian inference, maximum likelihood and maximum parsimony, in order to explore the evolutionary relationships between the Erysimum species inhabiting these ranges. Analyses of concatenated sequences from the two genomes identified two main clades with no overlap in species composition so that samples from the same species fell within the same major clade. The phylogenetic relationships depicted by those two clades do not give support to the $E$. nevadense group, previously proposed on taxonomic grounds. In addition, our results indicated recurrent changes in flower colour in the Baetic Erysimum species although, alternatively, reticulate evolution, which is suggested by incongruent position of taxa in the different trees, may have also affected this trait.
\end{abstract}

Keywords: cpDNA, flower colour, nDNA, Erysimum nevadense group, secondary contact.

\section{INTRODUCTION}

Erysimum L. is one of the largest genera of the Brassicaceae, comprising more than 200 species, recently grouped in the unigeneric tribe Erysimeae (Couvreur \& al., 2010; Al-Shebaz, 2012). The evolutionary history of this genus is complex, with recurrent events of interspecific hybridization and polyploidization (Clot, 1992; Ancev, 2006; Marhold \& Lihová, 2006). In fact, Erysimum is one of the few crucifer polybasic genera (i.e., characterized by multiple base chromosome numbers; Warwick \& al., 2006). Reticulate evolution is likely to be behind

\section{Resumen}

Abdelaziz, M., Muñoz-Pajares, A.J., Lorite J., Herrador, M.B., Perfectti, F. \& Gómez, J.M. 2014. Relaciones filogenéticas en Erysimum (Brassicaceae) de las Cordilleras Béticas (SE Península Ibérica). Anales Jard. Bot. Madrid 71(1): e005.

Las cordilleras Béticas, localizadas en el sudeste de la Península Ibérica, representan una importante zona para la biodiversidad de la cuenca mediterránea, constituyendo uno de los refugios glaciares más destacados de plantas vasculares en Europa. A pesar de su extensión relativamente limitada, las cordilleras Béticas albergan casi el 50\% del total de las especies endémicas de Erysimum de la Península Ibérica. Erysimum es un género ampliamente distribuido, que se ha diversificado profusamente en la región mediterránea, con más de un centenar de especies descritas en dicha área, del total de las alrededor de 200 especies incluidas en el género. Usamos dos regiones de ADN plastidial (ndhFy trnT-L) y una región de ADN nuclear (ITS1-5.8S rDNA-ITS2), con una longitud total de 3.556 pb, para llevar a cabo análisis filogenéticos mediante inferencia bayesiana, máxima verosimilitud y máxima parsimonia, con el fin de explorar las relaciones evolutivas entre las especies de Erysimum que habitan en éstas cordilleras. El análisis de secuencias concatenadas de los dos genomas identifica dos clados principales y las muestras de la misma especie aparecen siempre en un clado o en el otro pero no en ambos. Las relaciones filogenéticas que indican esos dos clados no apoyan la circunscripción del grupo taxonómico E. nevadense, previamente definido en dicho género. Además, los análisis indican cambios recurrentes en el color floral de las especies de Erysimum que habitan los Sistemas Béticos aunque la evolución reticulada, que sugiere la posición de algunos taxones en uno y otro árbol, puede haber también afectado a este rasgo, lo que sería una hipótesis alternativa.

Palabras clave: ADN cloroplastidial, color floral, ADN ribosómico nuclear, grupo Erysimum nevadense, contacto secundario.

the existence of species complexes and cryptic species which are common in Erysimum (Ancev, 2006; Turner, 2006; Abdelaziz \& al., 2011), and havecaused many taxonomic conflicts (Favarger 1978; Nieto Feliner 1991). As a consequence of this taxonomic complexity, the number of species included in the genus ranges from 180 to 223 , depending on the taxonomic approach used (Al-Shehbaz \& al., 2006; Warwick \& al., 2006; Koch \& Al-Shehbaz, 2008).

The genus Erysimum is primarily distributed in Eurasia, although some species occur in North and Central America, North Africa and the Macaronesian Islands (Al-Shehbaz 
\& al., 2006; Warwick \& al., 2006; Koch \& Al-Shehbaz, 2008) and has diversified profusely in the Mediterranean region. More than 100 Erysimum species have been recognized in this area (Greuter \& al., 1986), 22 of them in the Iberian Peninsula (Nieto Feliner, 1993). Molecular evidence suggests that many of these species are inter-fertile and have hybridized in the past (Abdelaziz, 2013; Muñoz-Pajares, 2013).

The Baetic mountains, located in the southern Iberian Peninsula (Fig. 1), are a major hotspot of biodiversity in the Mediterranean Basin (Sainz-Ollero \& Hernández Bermejo 1985; Domínguez \& al., 1996; Blanca \& al., 1998; Médail \& Quézel, 1999; Quézel \& Médail, 1995). The geological history of the Baetic Mountains differs from the rest of the Iberian Peninsula since they share a common geological origin with the Rif Mountains in northern Morocco, and together form the Baetic-Rifean Arc (Lonergan \& White, 1997). More than 3,000 vascular plant species occur in the $45,000 \mathrm{~km}^{2}$ occupied by the Baetic mountains, and $40 \%$ of them are endemic to the Iberian Peninsula (Medina-Cazorla \& al. 2010). Such a high plant diversity has several non-exclusive causes. On the one hand, this area has acted as one of the most important glacial refugia for vascular plants in the Mediterranean region (Medail \& Diadema, 2009); on the other, local diversification sometimes leading to allopatric and peripatric speciation has been favoured by its complex topography (Lavergne \& al., 2012). Furthermore, its biogeographical connection with the North African Rif has facilitated migration from the Maghreb, enhancing plant diversity with African lineages (Lavergne \& al., 2012), as previously showed for other plant genera, as e.g.: Saxifraga, Hypochaeris, Cakile, Crithmum, Eryngium,
Halimione, Salsola and Cistus (Rodríguez-Sanchez \& al., 2008, and references therein).

Ten Erysimum species inhabit the Baetic Mountains, seven of them endemic to the area (Blanca \& al., 2009). The genus presents a range of life forms from perennial polycarpic (e.g., E. nevadense) to monocarpic annuals (e.g., E. incanum) that occur from the mountain tops (e.g., E. nevadense) to the lowlands (e.g., E. mediobispanicum or E. gomezcampoii) and are associated to different type of substrates (Table 1 ). The genus Erysimum also exhibits two flower colours in the species inhabiting the Baetic mountains (Table 1). In this study we explore the phylogenetic relationships among these wallflower species. There is a recently published phylogeny of the genus based on nuclear ribosomal DNA ITS sequence data that is mainly focused on Asian species and only covers a small representation of the Baetic and even the Iberian taxa (Moazzeni \& al. 2014).

\section{MATERIAL AND METHODS}

\section{Study system}

According to Flora Iberica (Nieto Feliner, 1993), nine outcrossing species of Erysimum are native to the Baetic Cordillera: E. baeticum Polatschek, E. cazorlense (Heywood) Holub, E. fitzii Polatschek, E. gomezcampoi Polatschek, E. mediohispanicum Polatschek, E. myriophyllum Lange, E. nevadense Reut., E. popovii Rothm, and E. rondae Polatschek. All these species belong to the section Erysimum L., along with the autogamous annual species E. incanum Kunze also growing in the area (see Fig. 1 and Table 1). Erysimum gomezcampoi, E. mediobispanicum, E. nevadense and E. rondae, together with $E$. merxmuelleri and E. ruscinonense

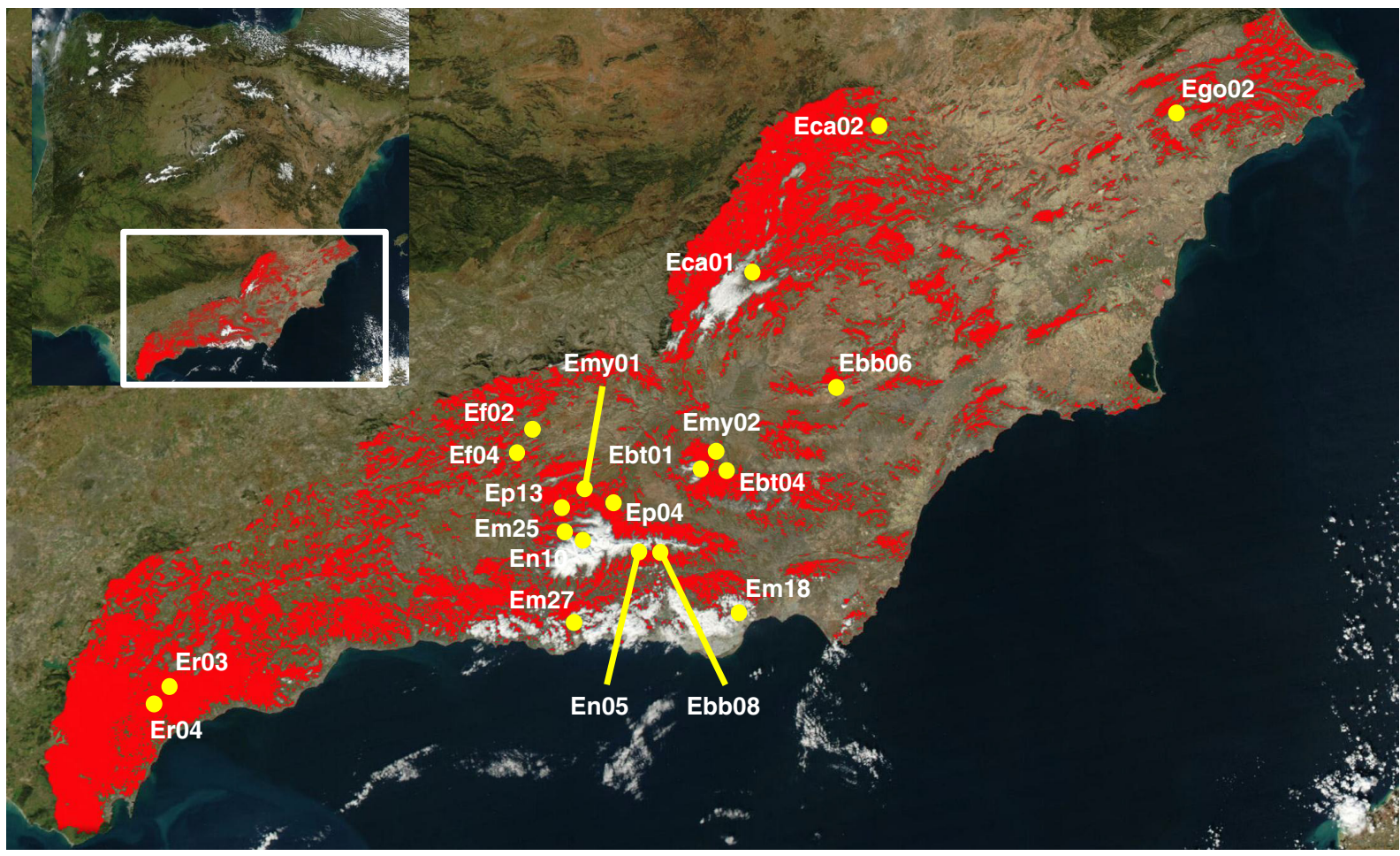

Fig. 1. Geographic location of the Baetic Mountains (in red) in South-East Spain and the populations sampled in the present study. Species, subspecies and population codes follow Tables 1 and 2 . 
Table 1. Population codes (Pop), distribution, altitude range, main substrate, life form, plant height and flower colour of the Erysimum species and subspecies inhabiting the Baetic Mountains. Endemic species are marked with † whereas those belonging to the nevadense group are marked with asterisk.

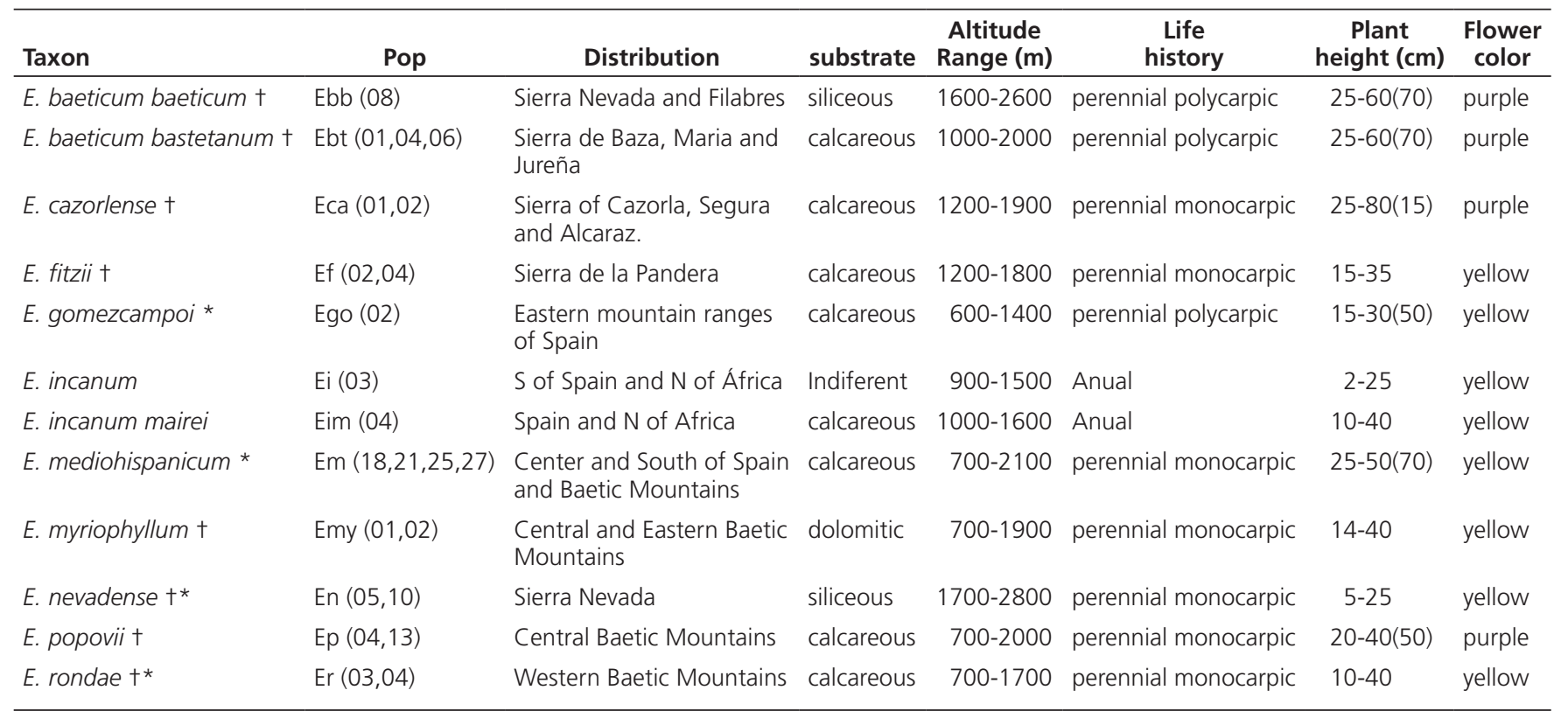

(from outside Baetic mountains), are considered microspecies that form a natural group called nevadense (Nieto Feliner, 1993 and Table 1).

\section{Phylogenetic analysis}

Fresh leaf tissue material was collected from at least two populations from each Baetic Erysimum species (except for E. gomezcampoi, which inhabits only one locality on the Baetic Mountains; and for E. baeticum subsp. bastetanum from Sierra de María, which was sampled from seeds of the germplasm bank of the Real Jardín Botánico de Madrid (Table 2). In total, 23 populations were sampled. This material was dried and preserved in silica gel until DNA extraction. We extracted DNA by using GenElute Plant Genomic DNA Miniprep Kit (Sigma-Aldrich, St. Louis, Missouri, USA) with at least $60 \mathrm{mg}$ of plant material crushed in liquid nitrogen.

We amplified three different DNA regions: two plastidial (ndhF, $2000 \mathrm{bp}$ and $\operatorname{trnT}-L, \sim 1300 \mathrm{bp}$ ) and one nuclear (ITS1-5.8S-ITS2, $710 \mathrm{bp}$ ). We used the following primers: ndhF5 (5' ATGGAACATACATATCAATATTCATGG 3') and ndhF2100 (5'CAAAGAAACTYGTAAKACSTACT CC 3') (Olmstead \& Sweere, 1994) to amplify $n d b F$; tabA (5' CATTACAAATGCGATGCTCT $\left.3^{\prime}\right)$ and tabD (5' GGGGATAGAGGGACTTGAAC 3’) (Taberlet \& al., 1991) for $\operatorname{trn}$ T-L; ITS1 (5' TCCGTAGGTGAACCTGCGG 3'), ITS2 (5' GCTGCGTTCTTCATCGATGC $\left.3^{\prime}\right)$, ITS3 $\left(5^{\prime}\right.$ GCATCGATGAAGAACGCAGC $\left.3^{\prime}\right)$ and ITS4 ( $5^{\prime}$ TCCTCCGCTTATTGATATGC $3^{\prime}$ ) primers for the ITS1-5.8s-ITS2 region (White \& al., 1990). PCR reactions were performed in a total volume of $50 \mu \mathrm{L}$, with the following composition: $5 \mu \mathrm{L} 10 \times$ buffer containing $\mathrm{MgCl}_{2}$ at $1.5 \mathrm{mmol} / \mathrm{L}$ (New England BioLabs), $0.1 \mathrm{mmol} / \mathrm{L}$ each dNTP, $0.2 \mu \mathrm{mol} / \mathrm{L}$ each primer and $0.02 \mathrm{U}$ Taq DNA polymerase (New England Biolabs). PCRs were performed in a
Gradient Master Cycler Pro S (Eppendorf) using an initial denaturing step of $3 \mathrm{~min}$ at $94^{\circ} \mathrm{C}$ and a final extension step of $3 \mathrm{~min}$ at $72^{\circ} \mathrm{C}$ in all the reactions. Reactions for $n d b F$ included 35 cycles of $94^{\circ} \mathrm{C}$ for $15 \mathrm{~s}, 47^{\circ} \mathrm{C}$ for $30 \mathrm{~s}$, and $72^{\circ} \mathrm{C}$ for $90 \mathrm{~s}$. Reactions for $\operatorname{trn} T-3^{\prime}$ trn L included 35 cycles $\left(94^{\circ} \mathrm{C}\right.$ $15 \mathrm{~s}, 53^{\circ} \mathrm{C} 30 \mathrm{~s}$, and $72^{\circ} \mathrm{C} 90 \mathrm{~s}$ ). Reactions for ITS1 also included 35 cycles $\left(94^{\circ} \mathrm{C} 15 \mathrm{~s}, 64^{\circ} \mathrm{C} 30 \mathrm{~s}\right.$, and $\left.72^{\circ} \mathrm{C} 45 \mathrm{~s}\right)$. For ITS2, reactions included 35 cycles of $94^{\circ} \mathrm{C} 15 \mathrm{~s}, 53^{\circ} \mathrm{C}$ $30 \mathrm{~s}$, and $72^{\circ} \mathrm{C} 45 \mathrm{~s}$ ).

PCR products were mixed with 0.15 volume of $3 \mathrm{M}$ sodium acetate, $\mathrm{pH} 4.6$ and 3 volumes $95 \%(\mathrm{v} / \mathrm{v})$ ethanol and subsequently purified by centrifuging at $4^{\circ} \mathrm{C}$. Amplicons were then sent to Macrogen (Geumchun-gu, Seoul, Korea; http://www.macrogen.com) to be sequenced, using the respective PCR primers and additional internal primers for $n d h F$ (ndhF599: $5^{\prime}$ TAGGTCTTTATTGGATAAC 3'; ndhF989-R: 5' TGATGTTAGCTCTAGGATGTATGGG 3'; and ndhF1354: 5' AAATGTCCTTCAAAAGTAAG 3'; Olmstead and Sweere, 1994) as well as for trnT-L regions (tabB: 5'TCTACCGATTTCGCCATATC 3'; and tabC: 5' CGAAATCGGTAGACGCTACG 3'; Taberlet \& al., 1991).

thaliana sequences from GenBank were used as outgroups, together with the Iranian species Erysimum passgalense Boiss. We tested for incongruence between the nuclear and plastid genes using Congruence Among Distance Matrices tests (CADM, Legendre \& Lapointe, 2004), as implemented in APE (Paradis, 2004; R Development Core Team. 2011). The phylogenetic information resulting from the three analyzed regions was significantly congruent $\left(\mathrm{W}=0.708, \chi^{2}=688.6, P=0.001\right.$ ). Sequences of different markers were thus concatenated on an individual basis and then aligned using the ClustalW (Thompson \& al., 1994) tool in BioEdit (Hall, 1999; Larkin \& al., 2007). The sequences reported in the present study have been deposited in GenBank (Table 2). 
Table 2. Population origin of the samples used in the phylogenetic analyses and GenBank accession numbers for the nuclear and plastidial sequences.

\begin{tabular}{|c|c|c|c|c|c|}
\hline \multirow[b]{2}{*}{ Taxon } & \multirow[b]{2}{*}{ Pop } & \multirow[b]{2}{*}{ Sample origin } & \multicolumn{3}{|c|}{ GenBank accession no. } \\
\hline & & & ITS1-5.8s-ITS2 & $n d h F$ & $\operatorname{trn} T-\operatorname{trn} L$ \\
\hline A. thaliana Heynh. & - & GeneBank & $\times 52322$ & AP000423 & AP000423 \\
\hline E. baeticum subsp. baeticum & Ebb08 & Spain: Almería, Sierra Nevada & KF445238 & KF445274 & KF445310 \\
\hline \multirow[t]{3}{*}{ E. baeticum subsp. bastetanum } & Ebt01 & Spain: Granada, Sierra de Baza & KF849859 & KF849843 & KF849876 \\
\hline & Ebt04 & Spain: Granada, Sierra de Baza & KF445237 & KF445273 & KF445309 \\
\hline & Ebt06 & Spain: Almería, Sierra de María & KF849860 & KF849844 & KF849877 \\
\hline \multirow[t]{2}{*}{ E. cazorlense } & Eca01 & Spain: Jaén, Sierra de Cazorla, Segura y las Villas & KF445242 & KF445278 & KF445314 \\
\hline & Eca02 & Spain: Albacete, Sierra de Alcázar & KF849861 & KF849845 & KF849878 \\
\hline \multirow[t]{2}{*}{ E. fitzii } & EfO2 & Spain: Jaén, Sierra de la Pandera & KF849862 & KF849846 & KF849879 \\
\hline & EfO4 & Spain: Jaén, Sierra de la Pandera & KF445248 & KF445284 & KF445320 \\
\hline E. gomezcampoi & Ego02 & Spain: Alicante, Font Roja & KF849863 & KF849847 & KF849880 \\
\hline E. incanum & $\mathrm{EiO3}$ & Morocco: Meknès-Tafilalet, Ifrane & KF849864 & HM235747 & HM235759 \\
\hline E. incanum mairei & Eim04 & Spain: Cuenca, Altobuey & KF849865 & KF849848 & KF849881 \\
\hline \multirow[t]{4}{*}{ E. mediohispanicum } & Em18 & Spain: Almeria, Sierra de Gador & KF849866 & KF849849 & KF849882 \\
\hline & Em21 & Spain: Granada, Sierra Nevada & KF849867 & KF849850 & KF849883 \\
\hline & Em25 & Spain: Granada, Sierra Nevada & KF445254 & KF445290 & KF445326 \\
\hline & Em27 & Spain: Granada, Sierra de Lújar & KF849868 & KF849851 & KF849884 \\
\hline \multirow[t]{2}{*}{ E. myriophyllum } & Emy01 & Spain: Granada, Sierra de Huétor & KF849869 & KF849852 & KF849885 \\
\hline & Emy02 & Spain: Granada, Sierra de Baza & KF849870 & KF849853 & KF849886 \\
\hline \multirow[t]{2}{*}{ E. nevadense } & En05 & Spain: Almeria, Sierra Nevada & KF849871 & KF849854 & KF849887 \\
\hline & En10 & Spain: Granada, Sierra Nevada & KF849872 & KF849855 & KF849888 \\
\hline E. passgalense & Epa01 & Iran: Karaj-Chalus road & KF445262 & KF445298 & KF445334 \\
\hline \multirow[t]{2}{*}{ E. popovii } & Ep04 & Spain: Granada, La Peza & KF849873 & KF849856 & KF849889 \\
\hline & Ep13 & Spain: Granada, Sierra de Huetor & KF445261 & KF445297 & KF445333 \\
\hline \multirow[t]{2}{*}{ E. rondae } & Er03 & Spain: Cádiz, Sierra de Grazalema & KF445265 & KF445301 & KF445337 \\
\hline & ErO4 & Spain: Cádiz, Sierra de Grazalema & KF849874 & KF849857 & KF849890 \\
\hline M. moricandioides & - & Spain: Almería & KF849875 & KF849858 & KF849891 \\
\hline
\end{tabular}

The alignments were manually reviewed, and a region of indels and a string of adenines in the trn T-L (positions 2880-3300 of the concatenated alignment) were deleted using the GBlocks Server (http://molevol.cmima.csic. es/castresana/Gblocks.html; Castresana, 2000) with the less stringent selection. In addition to estimating phylogenetic relationships over the concatenated matrix, we also analysed the nuclear sequences and plastidial sequences independently. For the three datasets we used maximum parsimony with PAUP v4.0 (Swofford, 2002), maximum likelihood (Felsenstein, 1973) with PhyML v2.4.4 (Guindon \& Gascuel, 2003) and Bayesian Markov chain Monte Carlo (MCMC) inference (Yang \& Rannala, 1997) with MrBayes v3.1.2 (Ronquist \& Huelsenbeck, 2003). The PhyML analysis was performed with default options, assuming a general time reversible (GTR) model. This was the best-fitting evolutionary model implemented in PhyML for the three concatenated regions as estimated by the program ModelTest v3.7, using the Akaike information criterion (Posada \& Crandall, 1998). Base frequencies, the proportion of invariable sites, substitution rates and the alpha parameter of the gamma distribution were estimated by PhyML. Branch support was estimated by both the approximate Likelihood Ratio Test (SH-like supports option) and by bootstrap (Felsenstein,
1985) with 1000 replicates. For Bayesian analysis, we used MrBayes on the online Bioportal of the University of Oslo (http://www.bioportal.uio.no/), partitioning the data into three regions, one for each locus used, and we estimated the best-fitting evolutionary model for each region using MrModelTest v2.3 (Nylander, 2004). The best-fitting evolutionary model obtained for $\mathrm{nDNA}$ region was $\mathrm{GTR}+\Gamma$, and for $n d h F$ and $\operatorname{trnT} T-L$ it was GTR+I and GTR+ $\Gamma$, respectively (Table 3). The analysis lasted for 4 million MCMC generations, with a sample frequency of every 100 generations, and we removed the first $25 \%$ of trees as burn-in, after checking trace files with the program Tracer v1.4 (Rambaut \& Drummond, 2007) to determine when the stationary phase was reached and the convergence of the two independent Bayesian MCMC runs. The consensus trees were visualized, edited, and exported using the program MEGA v4.0.2 (Tamura \& al., 2007), which was also used for the characterization of the sequences (Table 3 ).

\section{RESULTS}

In the phylogenetic analyses of the three data sets outgroup taxa, both external and congeneric, were maintained separate to the Baetic Erysimum species with the exception of 
Table 3. Characterization of DNA regions included in the present study. Number of variable sites [(variable sites/total sites)*100]; number of parsimony informative sites [((variable sites-singletons)/total sites)*100]; number of singleton sites [(singleton sites/variable sites)*100]. Percentage of the different nucleotides in the sequences are also given, as well as the models used per sequence.

\begin{tabular}{lcrrr}
\hline & ITS1-5.8S rDNA-ITS2 & ndhF & trnT-3'trnL & Combined \\
\hline Alligned base pairs & 708 & 2004 & 844 & 3556 \\
Number of variable sites (\%) & 20.19 & 5.73 & 10.90 & 9.84 \\
Number of parsimony informative sites (\%) & 6.07 & 1.04 & 1.54 & 2.16 \\
Number of singleton sites (\%) & 14.12 & 4.69 & 9.36 & 7.68 \\
$\% \mathrm{~A}$ & 24.8 & 29.5 & 39.0 & 30.8 \\
$\% \mathrm{C}$ & 26.2 & 14.6 & 14.6 & 16.9 \\
$\% \mathrm{G}$ & 26.3 & 15.7 & 16.0 & 17.9 \\
$\% \mathrm{~T}$ & 22.7 & 40.2 & 30.4 & 34.4 \\
Used models & $\mathrm{GTR}+\Gamma$ & $\mathrm{GTR}+\mathrm{T}$ & $\mathrm{GTR}+\Gamma$ & \\
\hline
\end{tabular}

the ITS tree in which the Asian species, $A$. passgalense, is sister to the outcrossing Baetic species and E. incanum is basal to all of them (Figs. 2, 3 and 4). In the inclusive analyses of $\mathrm{nDNA}$ and cpDNA, E. gomezcampoi is sister to the rest of the outcrossing Baetic Erysimum species, although this topology did not show a high support. The rest of the Baetic species were distributed in two main clades. Clade A included $E$. baeticum (both subspecies), E. popovii, E. mediohispanicum and $E$. nevadense with significant support, whereas Clade B included E. fitzii, E. cazorlense, E. myriophyllum and E. rondae (Fig. 2). Part of the populations belonging to the same species appeared as monophyletic, but some of the samples of E. cazorlense, E. myriophyllum, E. baeticum and E. mediohispanicum did not.

Despite the result of the test for congruence, the phylogenetic relationships shown by the nuclear region and plastidial regions were at variance. Comparing the $\mathrm{nDNA}$ tree and the combined tree, the composition of clade $\mathrm{A}$ and $\mathrm{B}$ holds but E. gomezcampoi is sister to Clade $\mathrm{A}$ in the nDNA tree instead of sister to the clade comprising $\mathrm{A}+\mathrm{B}$ (Figs. 2, 3).

However, the cpDNA tree was less resolved, neither clade A nor B appear and the distribution of taxa is very discordant compared to the nDNA tree. . For instance, one sample of E. popovii is sister to the rest of the outcrossing Baetic species and one of the samples of E. fitzii is sister to E. nevadense and E. baeticum p.p. (Fig. 4).

\section{DISCUSSION}

Some cautionary words are necessary when discussing the present phylogenetic results, because more Iberian and West-Mediterranean species from outside the Baetic Mountains would need to be included to verify our results. However, there are some tentative conclusions that can be drawn. The result of the test for congruence, which does not find significant discordance, is striking in view of the topologies of the cpDNA, and the nDNA. This may be due to the low resolution and low support of clades appearing in the cpDNA tree. The disparate positions of specific taxa (e.g., E. fitzii, E. popovii or E. mediobispanicum, on the cpDNA tree compared to the other two, suggest the occurrence of introgressive hybridization or incomplete lineage sorting events (Linder \& Rieseberg, 2004; Nieto Feliner \& Roselló,
2007). The latter cause is more likely in species with recent origin in which reciprocal monophyly for sampled genes has not yet been reached (van Oppen \& al. 2001), as many groups in the genus Erysimum apparentely are (Moazzeni $\&$ al. 2014). However, patterns such as the placement of $E$. mediobispanicum in the ITS tree with some of the species with which it co-occurs in sympatry (E. popovii, E. baeticum and E. nevadense), suggest introgressive hybridization events between taxa (Nieto Feliner \& Roselló, 2007). In spite of potential distorting events for the recovery of species phylogeny, our ITS data that is somehow reinforced in the combined analysis suggest that there are two main Erysimum clades in the Baetic Mountains, and all conspecific samples fall in one clade or the other, not in both. One clade (A) with significant support includes E. baeticum, E. popovii, E. nevadense and E. mediohispanicum, whereas the other one (B) includes E. fitzii, E. cazorlense, E. myriopbyllum and E. rondae although with no support (Fig. 2). Previous phylogenetic studies like Moazzeni \& al. (2014) or other works from our own group (Gómez \& al, 2014a, 2014b, 2014c) are not conclusive to support or question the existence of those two clades since their representation of taxa from the Iberian Peninsula is scarce. The two populations of E. incanum from outside the Baetic Mountains that were included in the analyses fall outside the outcrossing Baetic taxa.

According to our results, the E. nevadense group as considered by some authors (e.g. Nieto Feliner, 1993; Blanca \& al. 2009) does not have phylogenetic support, as the four (out of six species) that are studied here do not form a monophyletic group (Fig. 2). Thus, E. nevadense and E. mediobispanicum are located in the first clade, whereas $E$. rondae, is located in the other lineage; and the single sample of the fourth species, E. gomezcampoi, does not clear relationships in this study since it is sister to the outcrossing Baetic Erysimum in the combined tree but is sister to Clade $\mathrm{A}$ in the ITS tree (Figs. 2, 3). Nieto Feliner (1993) indicates that $E$. rondae sometimes displays an intermediate phenotype between the nevadense group and E. myriophyllum. In keeping with this notion, our analysis suggests a close evolutionary relationship between $E$. rondae and the latter species. In contrast, Blanca \& al. (2009) consider E. rondae a subspecies of E. mediohispanicum, a taxonomical status that is not supported by our phylogenetic analysis. 


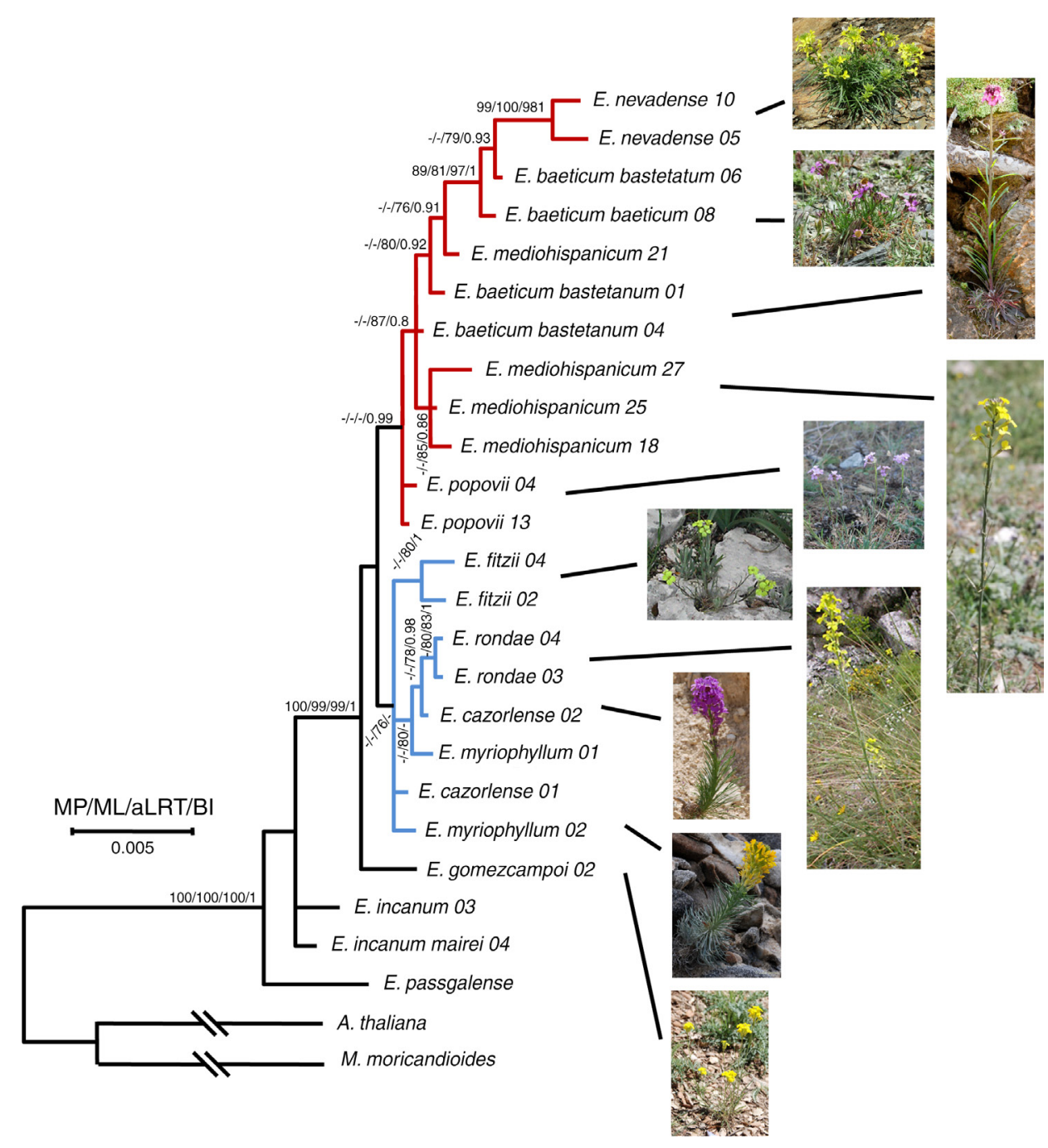

Fig. 2. Phylogenetic relationships of Erysimum taxa inhabiting the Baetic Mountains using the combined sequences from nuclear (ITS1-5.8S-ITS2) and plastidial (ndhF and trnT-L) DNA and three different methods. MP: branch support under Maximum Parsimony estimated by bootstrapping. / ML: branch support under Maximum likelihood estimated by bootstrapping. / aLRT: branch support under Maximum likelihood estimated by approximate likelihood ratio test. / BI: branch support values under Bayesian Inference are posterior probabilities. Only branch support values higher than $75 \%$ are shown. Clade A marked in red, clade B marked in blue.

The two subspecies of E. baeticum (subsp. baeticum and subsp. bastetanum), do not form a monophyletic group (Fig. 2). It is noteworthy that E. baeticum subsp. bastetanum from Sierra de María is grouped with the E. baeticum subsp. baeticum population from Sierra Nevada, even though Sierra de Baza (where the other two E. baeticum subsp. bastetanum populations were collected) is located between these two mountain ranges. Nieto Feliner (1992a) suggested that E. baeticum subsp. baeticum could have evolved as a consequence of hybridization between E. nevadense and the widespread subspecies E. baeticum subsp. bastetanum. This author invoked several circumstantial findings to support his hypothesis. First, E. nevadense and E. baeticum subsp. baeticum are phenotypically identical, apart from differing in petal colour (yellow and purple, respectively). Both taxa are short and polycarpic with multiple flowering stems arising directly from the rootstock rather than from the axillary leaflet fascicles (Nieto Feliner, 1992b). Erysimum nevadense and E. baeticum subsp. baeticum also share the type of substrate where they grow (siliceous), which is different from that where E. baeticum subsp. bastetanum occurs (Table 1). Moreover, according to Blanca \& al. (1992), E. nevadense is diploid $(2 \mathrm{n}=14)$, E. baeticum subsp.bastetanum is tetraploid $(2 \mathrm{n}=28)$, but E. baeticum subsp. baeticum can be tetraploid or octoploid $(2 n=56[n=28])$. Effectively, our phylogenetic analysis suggests a close relationship between E. baeticum subsp. baeticum and E. nevadense. We cannot rule out the hypothesis that E. baeticum subsp.baeticum evolved by hybridization, although further studies with additional populations and markers are needed to shed light on these questions.

Most Erysimum species have flowers with yellow petals. Specifically, purple-flowered species occur only in the Iberian Peninsula, the Macaronesian Islands, Near East (E. purpureum from Israel, Jordania, Lebanon, Syria and Turkey, E. lilacinum from Armenia, Azerbaijan and Iran, E. oleifolium from Irak, Iran, Jordania and Syria and E. pseudopurpureum from Turkey), Central Asia (E. violascens from 


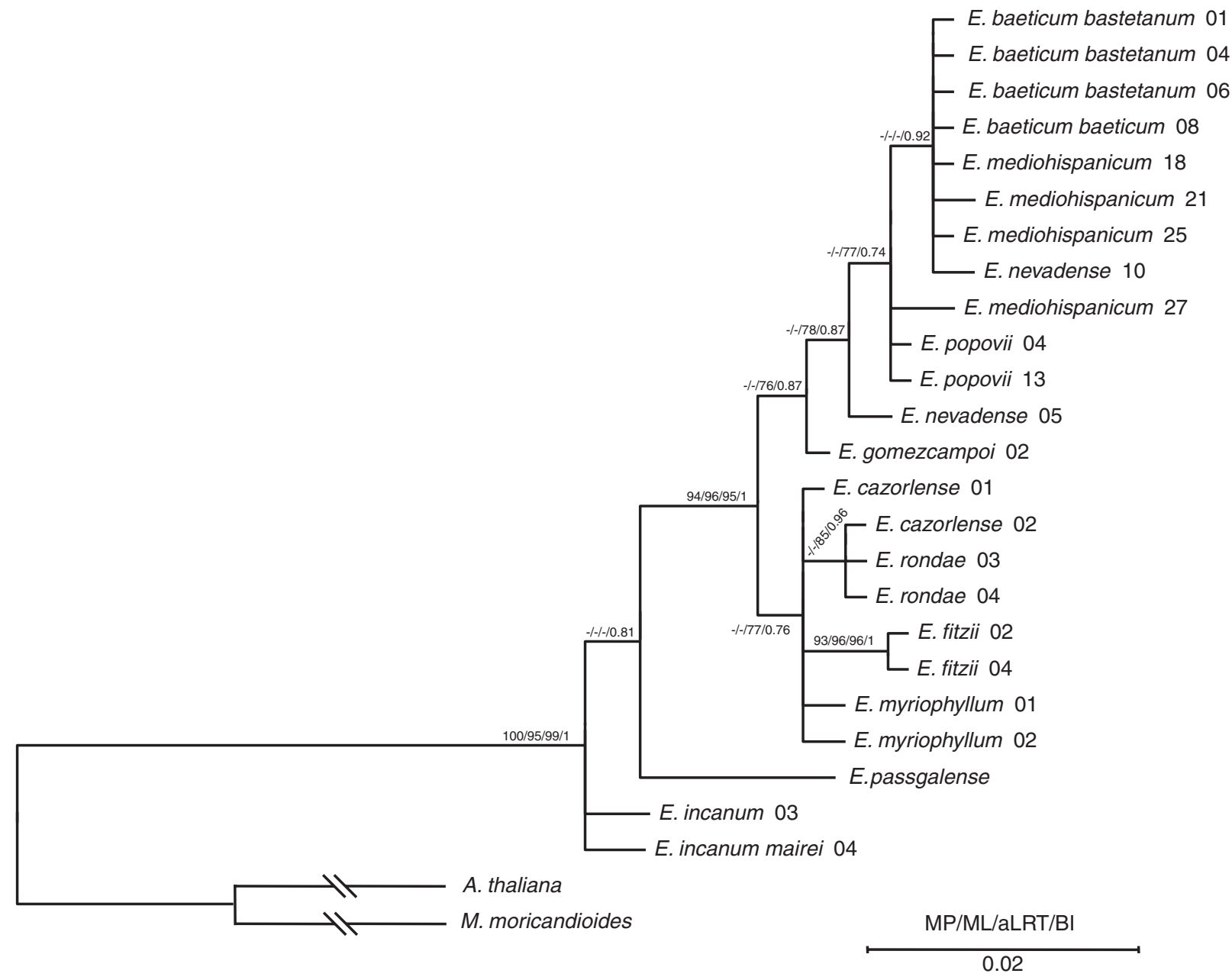

Fig. 3. Phylogenetic relationships based only on the nuclear region ITS1-5.8S-ITS2 for the Erysimum species inhabiting the Baetic Mountains. MP: branch support under Maximum Parsimony estimated by bootstrapping. / ML: branch support under Maximum likelihood estimated by bootstrapping. / aLRT: branch support under Maximum likelihood estimated by approximate likelihood ratio test. / BI: branch support values under Bayesian Inference are posterior probabilities. Only branch support values higher than $75 \%$ are shown.

Uzbekistan, E. samarkandicum from Tajikistan, and E. cyaneum from Uzbekistan, Kyrgyzstan and Tajikistan), China (E. funiculosum and E. roseum from Tibet and E. limprichtii from West China) and East Siberia (E. pallasi) (Taiyan \& al. 2001, Polatschek 2010, 2011). Despite the comparatively small geographical area of the Iberian Peninsula, it contains six purple-flowered taxa, four of them (E. cazorlense, E. baeticum subsp. baeticum, E. baeticum subsp. bastetanum and E. popovii) inhabiting the Baetic Mountains (Nieto Feliner, 1993). They have usually been considered a monophyletic group (Ball, 1990; Nieto Feliner, 1992c) or even a single species (Heywood, 1954). However, our phylogenetic analysis indicates that these species are not monophyletic and instead suggests that purple flowers appeared at least three times (Fig. 2). Since single or few mutations in the genes involved in the pigment biosynthetic pathways have been demonstrated to be responsible in petal colour shifts (Davies \& al., 1998; Ono \& al., 2006; Dick \& al., 2011), these evolutionary transitions in nature may be common. However, such conclusion has two caveats. First, it is intriguing that in the Western Mediterranean region purple-flowered Erysimum appear only in the Iberian Peninsula, even though the genus is frequent in other areas, such as Morocco (5 Erysimum species, Abdelaziz \& al., 2011), or Italy (17 species and one subspecies, Polatschek, 1982). The scarcity of purple flowers in the region probably was an implicit argument for a single evolutionary event in the Iberian Peninsula. Second, introgression or hybridization might be involved the occurrence of purple flowers in five taxa in the Iberian Peninsula (see above), in which case the number of independent appearances of this flower trait would be reduced. It would be interesting to identify the role of the reticulate evolution together with the ecological factors that might promote recurrent evolution of purple flowers in Iberian Erysimum if this was the case.

Most Erysimum species inhabiting the Baetic Mountains are allopatric, since their distribution does not overlap at present (Blanca \& al., 2009). However, several species cooccur in the same mountains and have some sympatric populations. Erysimum baeticum subsp. bastetanum and E. myriophyllum are sympatric in some localities on the Sierra de Baza. Erysimum mediohispanicum is sympatric with several species, namely with E. popovii in one locality on Sierra Nevada and in another locality on Sierra de Huétor; with 


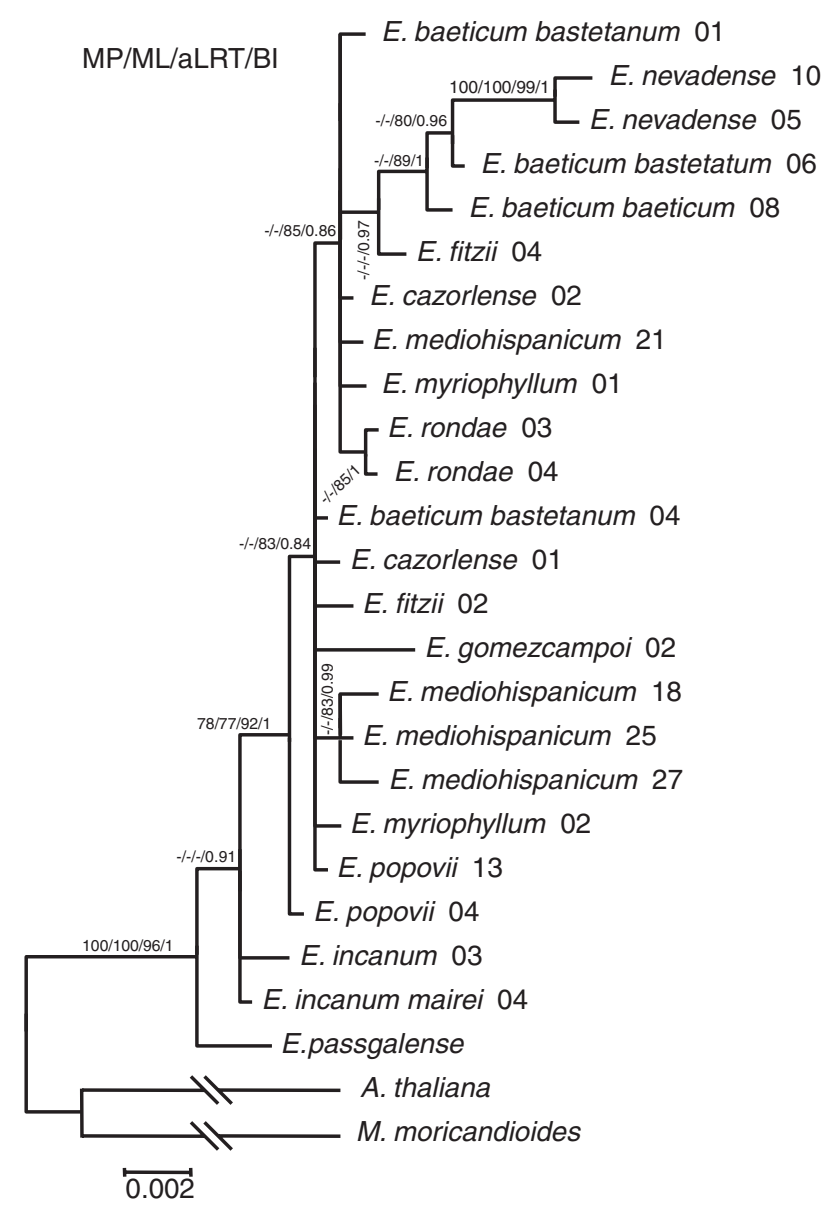

Fig. 4. Phylogenetic relationships based only on the plastidial DNA (ndhF and trnT-L) for the Erysimum species inhabiting the Baetic Mountains. MP: branch support under Maximum Parsimony estimated by bootstrapping. / ML: branch support under Maximum likelihood estimated by bootstrapping. / aLRT: branch support under Maximum likelihood estimated by approximate likelihood ratio test. / BI: branch support values under Bayesian Inference are posterior probabilities. Only branch support values higher than $75 \%$ are shown.

E. baeticum subsp. bastetanum in one locality of Sierra Jureña; with E. myriophyllum in one locality of Sierra de Cazorla and with E. nevadense in a narrow part of the Sierra Nevada. We can hypothesize that the sympatric Erysimum species in the Baetic Mountains evolved allopatrically, and probably made secondary contact as a result of the expansion of the geographic range of one or both members of the sympatric pair. The consequences of these hypothetical secondary contacts may have influenced the evolutionary history of the genus in the region but certainly to substantiate this statement each case has to be the subject of a detailed study.

With the caution imposed by the fact that we have not included in this study other non-Baetic related species, implying that some clades could not represent the complete evolutionary history of the genus in these mountains, we identify three relevant outcomes from the present work. First, with the exception of E. incanum, the Erysimum species inhabiting the Baetic Mountains are divided in at least two main clades. Second, there is no phylogenetic support for the E. nevadense taxonomic group, since some of the species included in this group are more related to species not included in it. Third, changes in flower colour in the evolution of Baetic Erysimum species appear to have been recurrent and/or reticulate events may have significantly influenced this trait.

\section{ACKNOWLEDGMENTS}

The authors thank to Gonzalo Nieto Feliner for his editing effort, and to Juli Caujapé-Castells and an anonymous Reviewer for their constructive comments on a previous version of this work. We are grateful to Modesto Berbel and Juande Fernandez for assistance during the field sampling and to Matthew Clarke for reviewing the English. This study has been supported by MARM (078/2007), Junta de Andalucía (P07-RNM-02869 and P11-RNM-7676), MONTES Consolider-Ingenio (CSD2008-00040), and Spanish MCyT (CGL2009-07015, and CGL2012-34736) grants. AJMP and MA were supported by Spanish Education and Science grants AP-200600685 and BES-2007-14206, respectively.

\section{REFERENCES}

Abdelaziz, M., Lorite, J., Muñoz-Pajares, A.J., Herrador, M.B., Perfectti, F. \& Gómez, J.M. 2011. Using complementary techniques to distinguish cryptic species: A new Erysimum (Brassicaceae) species from North Africa. American Journal of Botany 98: 1049-1060. http://dx.doi. org/10.3732/ajb.1000438.

Abdelaziz, M. 2013. How species are evolutionarily maintained: Pollinatormediated divergence and hybridization in Erysimum mediohispanicum and $\mathrm{E}$. nevadense. $\mathrm{PhD}$ thesis.

Al-Shehbaz, I.A. 2012. A generic and tribal synopsis of the Brassicaceae (Cruciferae). Taxon 61: 931-954.

Al-Shehbaz, I.A., Beilstein, M.A. \& Kellogg, E.A. 2006. Systematics and phylogeny of the Brassicaceae (Cruciferae): An overview. Plant Systematics and Evolution 259: 89-120. http://dx.doi.org/10.1007/ s00606-006-0415-z.

Ancev, M. 2006. Polyploidy and hybridization in Bulgarian Brassicaceae: Distribution and evolutionary role. Phytologia Balcanica 12: 357-366.

Ball, P.W. 1990. Notes on the genus Erysimum L. in Europe. Botanical Journal of the Linnean Society 103: 200-213.

Blanca, G., Morales C. \& Ruiz-Rejón, M. 1992. El género Erysimum L. (CRUCIFERAE) en Andalucía (Espa-a). Anales del Jardín Botánico de Madrid 49: 201-214.

Blanca, G., Cueto, M., Martínez-Lirola, M.J. \& Molero-Mesa, J. 1998. Threatened vascular flora of Sierra Nevada (Southern Spain). Biological Conservation 86: 269-285. http://dx.doi.org/10.1016/ S0006-3207(97)00169-9.

Blanca, G., Cabezudo, B., Cueto, M., Fernández López, C. \& Morales Torres, C. 2009, eds. Flora vascular de Andalucia Oriental. Vol. 3: Rosaceae-Lentibulariaceae. Consejeria de Medio Ambiente. Junta de Andalucia. Sevilla. Spain

Cansaran, A., Ergen Akaçin, O. \& Kandemira, N. 1997. Study on the Morphology, Anatomy and Autecology of Erysimum amasianum Hausskn. \& Bornm. (Brassicaceae) Distributed in Central Black Sea Region (Amasya-Turkey). International Journal of Science and Technology 2: 13-24.

Castresana, J. 2000. Selection of conserved blocks from multiple alignments for their use in phylogenetic analysis. Molecular Biology and Evolution 17: 540-552. http://dx.doi.org/10.1093/oxfordjournals. molbev.a026334.

Clot, B. 1992. Caryosystématique de quelques Erysimum L. dans le nord de la Péninsule Ibérique. Anales del Jardín Botánico de Madrid 49: 215-229.

Couvreur, T.L.P., Franzke, A., Al-Shehbaz, I.A., Bakker, F.T., Koch, M.A. \& Mummenhoff, K. 2010. Molecular Phylogenetics, Temporal Diversification, and Principles of Evolution in the Mustard Family (Brassicaceae). Molecular Biology and Evolution 27: 55-71. http:// dx.doi.org/10.1093/molbev/msp202.

Davies, K.M., Bloor, S.J., Spiller, G.B. \& Deroles, S.C. 1998. Production of yellow colour in flowers: redirection of flavonoid biosynthesis in Petunia. The Plant Journal 13: 259-266. http://dx.doi org/10.1046/j.1365-313X.1998.00029.x.

Dick, C.A., Buenrostro, J., Butler, T., Carlson, M.L., Kliebenstein, D.J. \& Whittall, J.B. 2011. Arctic mustard flower color polymorphism controlled by petal-specific down-regulation at the threshold of the anthocyanin biosynthetic pathway. PLOS ONE 6: e18230. http://dx.doi. org/10.1371/journal.pone.0018230.

Domínguez, F., Galicia, D., Moreno-Rivero, L., Moreno-Sáiz, J.C. \& SaínzOllero, H. 1996. Threatened plants in Peninsular and Balearic Spain: a 
report based on the EU Habitats Directive. Biological Conservation 76: 123-133. http://dx.doi.org/10.1016/0006-3207(95)00107-7.

Favarger, C. 1978. Un example de variation cytogeographique: Le complexe de L'Erysimum grandiflorum-sylvestre. Anales del Instituto Botánico A. J. Cavanilles 35: 361-398.

Felsenstein, J. 1973. Maximum likelihood and minimum-steps methods for estimating evolutionary trees from data on discrete characters Systematic Zoology 22: 240-249. http://dx.doi.org/10.2307/2412304.

Felsenstein, J. 1985. Confidence limits on phylogenies: an approach using the bootstrap. Evolution 39: 783-791. http://dx.doi.org/10.2307/2408678.

Gavrilets, S. 2004. Fitness landscapes and the origins of species. Princeton University Press, Princeton, NJ.

Gómez, J.M., Muñoz-Pajares, A.J., Abdelaziz, M., Lorite, J. \& Perfectti, F. 2014a. Evolution of pollination niches and floral divergence in the generalist plant Erysimum mediohispanicum. Annals of Botany 113: 237-249. http://dx.doi.org/10.1093/aob/mct186.

Gómez, J.M., Perfectti, F. \& Klingenber, C. 2014b. The role of pollinators in the evolution of corolla shape integration in a pollination-generalist plant clade. Philosophical Transactions of the Royal Society B 369: 20130257. http://dx.doi.org/10.1098/rstb.2013.0257.

Gómez, J.M., Perfectti, F., Abdelaziz, M., Lorite, J., Múñoz-Pajares, A.J. \& Valverde J. 2014c. Evolution of pollination niches in a generalist plant clade. New Phytologist 205, 2015: 440-453. http://dx.doi.org/10.1111/ nph.13016.

Greuter, W., Burdet, H.M. \& Long, G. 1986. Med-checklist 3, Dicotyledones (Convolvulaceae-Labiatae). Conservatoire et Jardin botaniques de la Ville de Genève. Genève, Italy.

Guindon, S. \& Gascuel, O. 2003. A simple, fast and accurate algorithm to estimate large phylogenies by maximum likelihood. Systematic Biology 52: 696-704. http://dx.doi.org/10.1080/10635150390235520.

Hall, T.A. 1999. BioEdit: A user-friendly biological sequence alignment editor and analysis program for Windows 95/98/NT. Nucleic Acids Symposium Series 41: 95-98.

Heywood, V.H. 1954. Notulae criticae ad floram hispaniae pertinentes, I. Bulletin of the British Museum (Natural History), Botany 1: 81-122.

Kevan, P.G. 1972. Floral colors in the high arctic with reference to insectflower relations and pollination. Canadian Journal of Botany 50: 22892316. http://dx.doi.org/10.1139/b72-298.

Koch, M.A. \& Al-Shehbaz, I.A. 2008. Molecular systematics and evolution of "wild" crucifers (Brassicaceae or Cruciferae). In P. K. Gupta [ed.], Biology and breeding of crucifers. 1-19. Taylor and Francis, London, UK.

Larkin, M.A., Blackshields, G., Brown, N.P., Chenna, R., McGettigan, P.A., McWilliam, H., Valentin, F., Wallace, I.M., Wilm, A., Lopez, R. Thompson, J.D., Gibson, T.J. \& Higgins, D.G. 2007. Clustal W and Clustal X version 2.0. Bioinformatics 23: 2947-2948. http://dx.doi. org/10.1093/bioinformatics/btm404

Lavergne, S., Hampe, A. \& Arroyo, J. 2012. In and out of Africa: how did the Strait of Gibraltar affect plant species migration and local diversification? Journal of Biogeography 39: 204-214.

Legendre, P. \& Lapointe, F.J. 2004. Assessing the congruence among distance matrices: single malt Scotch whiskies revisited. Australian and New Zealand Journal of Statistics 46: 615-629. http://dx.doi org/10.1111/j.1467-842X.2004.00357.x.

Linder, C.R. \& Rieseberg L.H. 2004. Reconstructing patterns of reticulate evolution in plants. American Journal of Botany 91: 1700-1708. http:// dx.doi.org/10.3732/ajb.91.10.1700.

Lonergan, L. \& White, N. 1997. Origin of the Betic-Rif mountain belt. Tectonics 16: 504-522. http://dx.doi.org/10.1029/96TC03937.

Marhold, K. \& Lihová, J. 2006. Polyploidy, hybridization and reticulate evolution: lessons from the Brassicaceae. Plant Systematics and Evolution 259: 143-174. http://dx.doi.org/10.1007/s00606-006-0417-x.

Médail, F. \& Diadema, K. 2009. Glacial refugia influence plant diversity patterns in the Mediterranean basin. Journal of Biogeography 36: 12221345. http://dx.doi.org/10.1111/j.1365-2699.2008.02051.x.

Médail, F. \& Quézel, P. 1999. Biodiversity Hotspots in the Mediterranean Basin: Setting Global Conservation Priorities. Conservation Biology 13: 1510-1513. http://dx.doi.org/10.1046/j.1523-1739.1999.98467.x.

Medina-Cazorla, J.M., Garrido-Becerra, J.A., Mendoza Fernández, A., Pérez-García, F.., Salmerón, E., Gil, C. \& Mota Poveda, J.F. 2010. Biogeography of the Baetic mountains (SE Spain): A historical approach using cluster and parsimony analyses of endemic dolomitophytes. Plant Biosystems 144: 111-120. http://dx.doi.org/10.1080/ 11263500903367983

Moazzeni, H., Zarre, S., Pfeil, B.E., Bertrand, Y., German, D.A., Al-Shehbaz, I. A., Mummenhoff, K. \& Oxekman, B. 2014. Phylogenetic perspectives on diversification, biogeography and character evolution in the species-rich genus Erysimum (Erysimeae; Brassicaceae) based on a densely sampled ITS approach. Botanical Journal of the Linnean Society 175: 497-522. http://dx.doi.org/10.1111/boj.12184.

Muñoz-Pajares, A.J. 2013. Erysimum mediohispanicum at the evolutionary crossroad: Phylogeography, phenotype, and pollinators. $\mathrm{PhD}$ thesis.

Feliner, G.N. \& Rosselló J.A. 2007. Better the devil you know? Guidelines for insightful utilization of nrDNA ITS in species-level evolutionary studies in plants. Molecular Phylogenetics and Evolution 44: 911-919. http://dx.doi.org/10.1016/j.ympev.2007.01.013.

Nieto Feliner, G. 1991. Breeding systems and related floral traits in several Erysimum (Cruciferae). Canadian Journal of Botany 69 : 2515-2521. http://dx.doi.org/10.1139/b91-313.

Nieto Feliner, G. 1992a. Los Erysimum orófilos nevadenses de flor amarilla y purpureo-violácea: ¿son coespecíficos? Anales delJardín Botánico de Madrid 50: 272-274

Nieto Feliner, G. 1992b. Life-form and systematics in the Iberian Erysimum (Cruciferae). Anales del Jardín Botánico de Madrid 49: 303-308.

Nieto Feliner, G. 1992c. Multivariate and cladistic analyses of the purpleflowered species of Erysimum (Cruciferae) from the Iberian Peninsula. Plant Systematics and Evolution 180: 15-28. http://dx.doi.org/10.1007/ BF00940395.

Nieto Feliner, G. 1993. Erysimum L. In: Castroviejo, S. \& al. (eds.), Flora iberica. Vol. IV. Cruciferae-Monotropaceae: 48-76. Real Jardín Botánico, CSIC. Madrid.

Nylander, J.A.A. 2004. MrModeltest v2 [computer program]. Evolutionary Biology Center, Uppsala University, Uppsala, Sweden.

Olmstead, R.G. \& Sweere, J.A. 1994. Combining data in phylogenetic systematics: An empirical approach using three molecular data sets in the Solanaceae. Systematic Biology 43: 467-481. http://dx.doi.org/10.1093/ sysbio/43.4.467.

Ono, E., Fukuchi-Mizutani, M., Nakamura, N., Fukui, Y., YonekuraSakakibara, K., Yamaguchi, M., Nakayama, T., Tanaka, T., Kusumi, T. \& Tanaka, Y. 2006. Yellow flowers generated by expression of the aurone biosynthetic pathway. Proceeding of the National Academy of Sciences, USA 103: 11075-11080. http://dx.doi.org/10.1073/pnas. 0604246103

Paradis, E., Claude, J. \& Strimmer, K. 2004. APE: analyses of phylogenetics and evolution in R language. Bioinformatics 20: 289-290. http://dx.doi. org/10.1093/bioinformatics/btg412.

Polatschek, A. 1975. Die Gattung Erysimum auf den Kapverden, Kanaren und Madeira. Annalen des Naturbistorisches Museum in Wien 80: 93-103.

Polatschek, A. 1982. Erysimum. - In Pignatti, S., (ed.): Flora d'Italia 1: 382 389. Bologna: Edagricole. Italy.

Polatschek, A. 1986. Erysimum. In A. Strid [ed.], Mountain flora of Greece, 1: 239-247. Cambridge University Press, Cambridge, UK.

Polatschek, A. 2010. Revision der Gattung Erysimum (Cruciferae)-Teil 1-Russland, die Nachfolgestaaten der USSR (excl. Georgien, Armenien, Azerbaidzan), China, Indien, Pakistan, Japan und Korea. Annalen des Naturbistorisches Museum in Wien. 111: 181-275.

Polatschek, A. 2011. Revision der gattung Erysimum (Cruciferae), Teil 2: Georgien, Armenien, Azerbaidzan, Türkei, Syrien, Libanon, Israel, Jordanien, Irak, Iran, Afghanistan. Annalen des Naturbistorisches Museum in Wien 112: 369-497.

Posada, D. \& Crandall, K.A. 1998. MODELTEST: Testing the model of DNA substitution. Bioinformatics 14: 817-818. http://dx.doi. org/10.1093/bioinformatics/14.9.817

Quézel, P., \& Médail, P. 1995. La région circum-méditerranéene, centre mondial majeur de biodiversité végétale. Actes des Gèmes rencontres de L'Agence Régionale pour L'Environnmentn Provence-Alpes-Côte D'Azur. Colloque Scientifique Internationale BioMes.

Rambaut, A. \& Drummond, A.J. 2007. Tracer v1.4 [computer program] URL: http://beast.bio.ed.ac.uk/Tracer.

R Development Core Team. 2011. R: a language and environment for statistical computing. R Foundation for Statistical Computing, Vienna, Austria. Available at http://www.R-project.org

Rodríguez-Sánchez, F., Pérez-Barrales, R., Ojeda, F., Vargas, P. \& Arroyo, J. 2008. The Strait of Gibraltar as a melting pot for plant biodiversity. Quaternary Science Reviews 27: 2100-2117.

Ronquist, F. \& Huelsenbeck, J. 2003. MrBayes 3: Bayesian phylogenetic inference under mixed models. Bioinformatics 19: 1572-1574.

Sainz-Ollero, H. \& Hernández-Bermejo, J.E. 1985. Sectorización fitogeográfica de la Península Ibérica e Islas Baleares: la contribución de su endemoflora como criterio de semejanza. Candollea 40: 485-508.

Swofford, D.L. 2002. PAUP*: Phylogenetic analysis using parsimony ("and other methods), beta version 4.0. Sinauer, Sunderland, Massachusetts, USA. 
Taberlet, P., Gielly, L., Pautou, G. \& Bouvet, J. 1991. Universal primers for amplification of three non-coding regions of chloroplast DNA. Plant Molecular Biology 17: 1105-1109. http://dx.doi.org/10.1007/BF00037152.

Taiyan, Z., Lianli, L., Guang, Y., Dorofeyev, V. I. \& Al-Shehbaz, I. A. 2001. Erysimum. Flora of China 8: 163-169.

Tamura, K., Dudley, J., Nei, M. \& Kumar, S. 2007. MEGA4: Molecular Evolutionary Genetics Analysis (MEGA) software version 4.0. Molecular Biology and Evolution 24: 1596-1599. http://dx.doi.org/10.1093/molbev/ msm092.

Thompson, J.D., Higgins, D.G. \& Gibson, T.J. 1994. CLUSTAL W: Improving the sensitivity of progressive multiple sequence alignment trough sequence weighting, position specific gap penalties and weight matrix choice. Nucleic Acids Research 22: 4673-4680. http://dx.doi. org/10.1093/nar/22.22.4673.

Turner, B.L. 2006. Taxonomy and nomenclature of the Erysimum asperum -E. capitatum complex (Brassicaceae). Phytologia 88: 279-287.

van Oppen, M.J.H., McDonald, B.J., Willis, B. \& Miller, D.J. 2001. The Evolutionary History of the Coral Genus Acropora (Scleractinia, Cnidaria) Based on a Mitochondrial and a Nuclear Marker: Reticulation,
Incomplete Lineage Sorting, or Morphological Convergence? Molecular Biology and Evolution 18: 1315-1329. http://dx.doi.org/10.1093/ oxfordjournals.molbev.a003916.

Warwick, S.I., Francis, A. \& Al-Shehbaz, I.A. 2006. Brassicaceae: Species checklist and database on CD-ROM. Plant Systematics and Evolution 259: 249-258. http://dx.doi.org/10.1007/s00606-006-0421-1.

White, T.J., Bruns, T., Lee, S. \& Taylor, J.W. 1990. Amplification and direct sequencing of fungal ribosomal RNA genes for phylogenetics. In M.A. Innis, D.H. Gelfand, J.J. Sninsky, and T.J. White [eds.], PCR protocols: A guide to methods and applications. San Diego Academic Press, San Diego, California, USA

Yang, Z. \& Rannala, B. 1997. Bayesian phylogenetic inference using DNA sequences: A Markov chain Monte Carlo method. Molecular Biology and Evolution 14: 717-724. http://dx.doi.org/10.1093/oxfordjournals. molbev.a025811.

Editor asociado: G. Nieto Feliner Received: 21-XI-2013 Accepted: 17-X-2014 